\title{
Titanium and Copper Oxide Based Catalysts for the Insitu Reactions of Methanation and Desulfurization in the Removal of Sour Gases from Simulated Natural Gas
}

\author{
W.A. Wan Abu Bakar*, M.Y. Othman, R. Ali, K.Y. Ching, J. Mohd. Nasir \\ Department of Chemistry, Faculty of Science, Universiti Teknologi Malaysia, 81310 UTM Skudai, Johor, Malaysia. \\ Accepted 15 September 2009, Available online 17 December 2009
}

\begin{abstract}
The objective of this novel catalyst development is to achieve both low temperature and high conversion of sour gases. Supported mixed metal oxide catalysts were prepared by impregnating the catalysts on alumina beads for the in-situ reactions of $\mathrm{H}_{2} \mathrm{~S}$ desulfurization and $\mathrm{CO}_{2}$ methanation from room temperature up to $200^{\circ} \mathrm{C}$. The results showed that the $100 \%$ conversion of $\mathrm{H}_{2} \mathrm{~S}$ to elemental sulfur for all of the potential catalysts was achieved at $100^{\circ} \mathrm{C}$. However, methanation of $\mathrm{CO}_{2}$ in the presence of $\mathrm{H}_{2} \mathrm{~S}$ yielded $0.4 \% \mathrm{CH}_{4}$ over $\mathrm{Fe} / \mathrm{Zn} / \mathrm{Cu} / \mathrm{Ti}-\mathrm{Al}_{2} \mathrm{O}_{3}$ catalyst and $0.7 \% \mathrm{CH}$ over Fe/Zn/Cu- $\mathrm{Al}{ }_{2} \mathrm{O}_{3}$ catalyst at maximum studied temperature of $200^{\circ} \mathrm{C}$. XPS results indicated that spinel compounds of $\mathrm{CuFe} \mathrm{O}_{4}$ and $\mathrm{Fe}_{3} \mathrm{O}_{4}$ act as the active sites on the Fe/ $\mathrm{Zn} / \mathrm{Cu}-$ $\mathrm{Al}_{2} \mathrm{O}_{3}$ and $\mathrm{Fe} / \mathrm{Zn} / \mathrm{Cu} / \mathrm{Ti}-\mathrm{Al}_{2} \mathrm{O}_{3}$ catalysts. The appearance of $\mathrm{Fe}^{3+}-\mathrm{OH}$ on $\mathrm{Fe} / \mathrm{Zn} / \mathrm{Cu} / \mathrm{Ti}^{-}-\mathrm{Al}_{2} \mathrm{O}_{3}$ catalyst increased its $\mathrm{H}_{2} \mathrm{~S}$ desulfurization activity. $\mathrm{N} 2$ adsorption-desorption analysis illustrated that $34 \%$ of the surface area of Fe/Zn/Cu- $\mathrm{Al}_{2} \mathrm{O}_{3}$ catalyst was reduced while Fe/Zn/Cu/Ti-Al $\mathrm{O}_{3}$ catalyst showed reduction of $17 \%$ after catalytic testing, which indicated the deactivation of the catalysts resulted from sulfur poisoning.
\end{abstract}

| Titanium | copper | methanation | desulfurization | natural gas |

( 2009 Ibnu Sina Insitute. All rights reserved. http://dx.doi.org/10.11113/mjfas.v5n2.293

\section{INTRODUCTION}

Crude natural gas is categorized as sour gas due to the contamination of carbon dioxide $\left(\mathrm{CO}_{2}\right)$ and hydrogen sulfide $\left(\mathrm{H}_{2} \mathrm{~S}\right)$. These corrosive elements may deteriorate the pipeline systems and become a safety hazard and also contribute to the environmental issue. Recently, the removal of these sour gases via chemical conversion techniques becomes the most promising technique. The catalysts for the $\mathrm{CO}_{2}$ methanation have been extensively studied because of their application in the conversion of $\mathrm{CO}_{2}$ gas to produce methane, which is the major component in natural gas. However, the presence of H2S in certain industrial processes is known to cause poisoning of the commercial nickel based catalyst.

The essential requirement for the correct selection of the oxide system is its ability to accept and to activate $\mathrm{CO}_{2}$ and $\mathrm{H} 2 \mathrm{~S}$. The acid nature of $\mathrm{CO}_{2}$ and $\mathrm{H}_{2} \mathrm{~S}$ necessitates the employment of a catalytic system with basic properties. The acid and redox properties of transition metal oxides could be changed by adding other oxides [1]. Investigation done by Wang et al. [2] found that the adsorption strength of $\mathrm{CO}_{2}$ is controlled by the Lewis basicity of a catalyst, d-band center of the metal surface, charge transfer from the metal surfaces to the chemisorbed $\mathrm{CO}_{2}$. The major reason for the less reactive of mixed metal oxide is its significantly complexity possibly presence of multiple oxidation states, variable local coordination, coexisting bulk and surface phases as well as different surface termination functionalities such as $\mathrm{M}-\mathrm{OH}, \mathrm{M}=\mathrm{O}$ or $\mathrm{M}-\mathrm{O}-\mathrm{M}$ [3]. Metal oxides are less active than metals, but they are stable in catalytic conditions.

Kulshreshtha et al. [4] have been reported that Fe-Ti-Sn intermetallics are capable of CO methanation and almost completely converted $\mathrm{CO}$ to methane at $323{ }^{\circ} \mathrm{C}$. This investigation concluded that the catalytic activity of the intermetallics is significantly improved by $\mathrm{Sn}$ substitution. Later, Pineda et al. [5] reported when zinc oxide and zinc ferrite catalysts were dopped with $\mathrm{Cu}$ and $\mathrm{Ti}$, their catalytic performance on $\mathrm{H}_{2} \mathrm{~S}$ desulfurization process could be increased. The addition of Ti may increase the stability of $\mathrm{ZnO}$ towards reducing agent such as $\mathrm{H}_{2}$. However, the addition of $\mathrm{Cu}$ do not affect the stability of catalyst but improve the catalyst performance by changing the surface of the catalyst during calcination and activation process. It has also been found that $\mathrm{CO}_{2}$ strongly chemisorbs on the $\mathrm{Fe}(110)$ surface with the strongest binding energy, whereas $\mathrm{CO}_{2}$ has moderate strength on the (111) surface of $\mathrm{Co}, \mathrm{Ni}, \mathrm{Rh}, \mathrm{Pd}$ with slightly positive binding energies [2]. 
The selection of support is considered as important since it may influence both the activity and selectivity of the reaction. It has been discovered that the addition of alumina may increase the methanation activity although there is a presence of low concentration of $\mathrm{H}_{2} \mathrm{~S}$ [6]. Therefore, $\mathrm{Al}_{2} \mathrm{O}_{3}$ is considered as the support for all the studied catalysts in this research.

Efforts to search for efficient catalyst and to explore new technologies in order to meet the demands of the economical feasibility of in-situ reactions of methanation and desulfurization for the purification of natural gas has not been extensively studied. The objective of this novel catalyst development is to achieve both low temperature and high conversion of sour gas. At low temperature, application of the novel catalyst in gas industry is more likely. However, problem arises because exothermic reaction of conversion of $\mathrm{CO}_{2}$ to $\mathrm{CH}_{4}$ is unfavorable at low temperature due to its low energy content.

\section{EXPERIMENTAL}

\subsection{Preparation of Catalysts}

The catalysts were prepared by wet impregnation method. The respective metal nitrate salt was dissolved with minimum amount of distilled water. Mixed catalysts solution was prepared by mixing appropriate amount of metal nitrate salts according to the atomic ratio. $\mathrm{Al}_{2} \mathrm{O}_{3}$ supported catalyst was prepared by impregnating the catalyst solution on $\mathrm{Al}_{2} \mathrm{O}_{3}$ beads support for 15 minutes. It was then dried at $80^{\circ} \mathrm{C}$ for 24 hours and calcined in air at $400{ }^{\circ} \mathrm{C}$ for 5 hours. To prepare $\mathrm{Ti}^{4+}$ sol for the Ti based catalyst, $6 \mathrm{~g}$ of polyethylene glycol (PEG) was dissolved with $600 \mathrm{~mL}$ of ethanol. After that, $31.8 \mathrm{~g}$ diethanolamine (DEA) followed by $85.2 \mathrm{~g}$ titanium (IV) isopropoxide (Ti(iso) ${ }_{4}$ ) was added when PEG was completely dissolved. $5.4 \mathrm{~mL}$ of distilled water was added and stirred for 10 minutes to get a homogeneous solution. $\mathrm{Al}_{2} \mathrm{O}_{3}$ beads were dipped into the $\mathrm{Ti}^{4+}$ sol and then dried in the oven at $80^{\circ} \mathrm{C}$ for 30 minutes. A mixed metal oxide with Ti sol was prepared by impregnating the resulted $\mathrm{Al}_{2} \mathrm{O}_{3}$ supported Ti with the respective metal oxide.

\subsection{Catalytic Activity Measurements}

The supported catalyst sample was packed into a cylindrical glass tube with diameter of $10 \mathrm{~mm}$ and length of $360 \mathrm{~mm}$ and was stored in the furnace of the home-built micro reactor. No pretreatment was done prior to beginning the heating experiment. Firstly, screening of the catalytic activity on individual reaction of $\mathrm{CO}_{2}$ and $\mathrm{H}_{2} \mathrm{~S}$ conversion was performed under 760 Torr pressure. The conversion of $\mathrm{CO}_{2}$ was screened from room temperature up to $500^{\circ} \mathrm{C}$ for the conversion of $\mathrm{CO}_{2}$ and up to $200^{\circ} \mathrm{C}$ for the conversion of $\mathrm{H}_{2} \mathrm{~S}$, with temperature rate of $5^{\circ} \mathrm{C} / \mathrm{min}$. After that, in-situ reactions of $\mathrm{CO} 2$ methanation and $\mathrm{H}_{2} \mathrm{~S}$ desulfurization were performed from room temperature up to $200^{\circ} \mathrm{C} . \mathrm{CO}_{2}$ and $\mathrm{H}_{2}$ gases were introduced into the reactor system in a stoichiometric ratio of 1: 4. About $2.5 \mathrm{~mL} / \mathrm{min}_{2} \mathrm{~S}$ gas was introduced into the gas stream. This composition is similar to the content of sour gases in Malaysian natural gas, which is $5 \%$ of $\mathrm{H}_{2} \mathrm{~S}$ and $20 \%$ of $\mathrm{CO}_{2}$. Screening on the produced gas stream was done by using FTIR analysis. Percentage conversion of $\mathrm{CO}_{2}$ and $\mathrm{H}_{2} \mathrm{~S}$ was obtained by calculating the peak area of their respective stretching band relative to the peak area of the gas during calibration without catalyst. Off line Gas Chromatography analysis was done on the product gas to determine the selectivity and yield of $\mathrm{CH}_{4}$ gas due to the low sensitivity of FTIR towards stretching band of $\mathrm{CH}_{4}$.

\subsection{Characterization of Catalysts}

\subsubsection{X-rays Photoelectron Spectroscopy}

The potential catalysts were characterized by using Kratos instrument XSAM HS surface analysis spectrometer with $\mathrm{Mg} \mathrm{K \alpha}$ x-rays source $(1253.6 \mathrm{eV})$. Sample was introduced into the spectrometer in flowing argon atmosphere, and evaporated at least $6 \times 109$ Torr before spectrum was recorded. The spectrum was taken at $10 \mathrm{~mA}$ and $14 \mathrm{kV}$ energy source at 2 sweeps.

\subsubsection{Nitrogen Adsorption Analysis}

The $\mathrm{N}_{2}$ adsorption-desorption isotherms for the catalysts were measured by Micromeritics ASAP 2010. All samples were evacuated at $120^{\circ} \mathrm{C}$ prior to the measurement. The specific surface area was calculated using the BET method. The total pore volume was determined at a relative pressure of $\mathrm{P} / \mathrm{Po}=0.99$. 


\section{RESULTS \& DISCUSSION}

\subsection{Catalytic Activity Measurement}

\subsubsection{Screening of the catalytic activity using FTIR spectroscopy}

A series of $\mathrm{Fe} / \mathrm{Zn} / \mathrm{Cu}-\mathrm{Al}_{2} \mathrm{O}_{3}$ catalyst containing three different ratio was prepared to optimize the copper content towards the catalyst. Table 1 compares the percentage conversion of $\mathrm{CO}_{2}$ and $\mathrm{H}_{2} \mathrm{~S}$ catalyzed over $\mathrm{Fe} / \mathrm{Zn} / \mathrm{Cu}-\mathrm{Al}_{2} \mathrm{O}_{3}$ catalyst with different ratios. According to Table 1, the optimum ratio for $\mathrm{Al}_{2} \mathrm{O}_{3}$ supported $\mathrm{Fe} / \mathrm{Zn} / \mathrm{Cu}-\mathrm{Al}_{2} \mathrm{O}_{3}$ catalyst is 4: 16: 80. 100 $\%$ conversion of $\mathrm{CO}_{2}$ was achieved over this catalyst at reaction temperature of $400{ }^{\circ} \mathrm{C}$, whereas $100 \% \mathrm{H}_{2} \mathrm{~S}$ desulfurization was achieved at $100{ }^{\circ} \mathrm{C} . \mathrm{Fe} / \mathrm{Zn} / \mathrm{Cu}(10: 30: 60)-\mathrm{Al}_{2} \mathrm{O}_{3}$ and $\mathrm{Fe} / \mathrm{Zn} / \mathrm{Cu}(3: 7: 90)-\mathrm{Al}_{2} \mathrm{O}_{3}$ catalysts only showed $98.9 \%$ and 89.9 $\%$ conversion of $\mathrm{CO}_{2}$ respectively, at maximum studied temperature of $500^{\circ} \mathrm{C}$. It could be seen that high concentration of $\mathrm{CuO}$ in the catalyst could increase the amount of surface oxygen on the catalyst surface. Therefore, the percentage conversion of $\mathrm{CO}_{2}$ over $\mathrm{Fe} / \mathrm{Zn} / \mathrm{Cu}$ (3: 7: 90) $-\mathrm{Al}_{2} \mathrm{O}_{3}$ catalyst was lowered. Relatively, smaller amount of $\mathrm{CuO}(\mathrm{Fe} / \mathrm{Zn} / \mathrm{Cu}=$ 10: 30: 60) on the catalyst could increase the adsorption of $\mathrm{H}_{2} \mathrm{~S}$. However, this catalyst is lack of surface oxygen that needed for desulfurization process as suggested in the previous study [7].

Table 1: Temperature for conversion of $\mathrm{CO}_{2}$ and $\mathrm{H}_{2} \mathrm{~S}$ over $\mathrm{Al}_{2} \mathrm{O}_{3}$ supported $\mathrm{Fe} / \mathrm{Zn} / \mathrm{Cu}$ catalysts with different ratios using simulated natural gas.

\begin{tabular}{ccc}
\hline Catalyst & \multicolumn{1}{c}{$\begin{array}{c}\mathrm{T}_{100} \mathrm{CO}_{2}{ }^{\mathrm{a}} \\
\left( \pm 0.5^{\circ} \mathrm{C}\right)\end{array}$} & $\begin{array}{c}\mathrm{T}_{100} \mathrm{H}_{2} \mathrm{~S} \\
\left( \pm 0.5^{\circ} \mathrm{C}\right)\end{array}$ \\
\hline $\mathrm{Fe} / \mathrm{Zn} / \mathrm{Cu}(10: 30: 60)-\mathrm{Al}_{2} \mathrm{O}_{3}$ & $500(98.9 \%)^{6}$ & 120 \\
$\mathrm{Fe} / \mathrm{Zn} / \mathrm{Cu}(4: 16: 80)-\mathrm{Al}_{2} \mathrm{O}_{3}$ & 400 & 100 \\
$\mathrm{Fe} / \mathrm{Zn} / \mathrm{Cu}(3: 7: 90)-\mathrm{Al}_{2} \mathrm{O}_{3}$ & $500(89.9 \%)^{b}$ & 100 \\
\hline
\end{tabular}

Temperature where $100 \%$ conversion was achieved

${ }^{b}$ Value in bracket is the $\%$ conversion of $\mathrm{CO}_{2}$ at maximum studied temperature of $500^{\circ} \mathrm{C}$

It has been reported by Pineda et al. [5] the presence of Ti may increase the $\mathrm{H}_{2} \mathrm{~S}$ desulfurization process at lower temperature. Therefore, optimization of titanium content towards $\mathrm{Fe} / \mathrm{Zn} / \mathrm{Cu} / \mathrm{Ti}-\mathrm{Al}_{2} \mathrm{O}_{3}$ catalyst was done. Table 2 shows the comparison of percentage conversion of $\mathrm{CO}_{2}$ and $\mathrm{H}_{2} \mathrm{~S}$ over $\mathrm{Fe} / \mathrm{Zn} / \mathrm{Cu} / \mathrm{Ti}-\mathrm{Al}_{2} \mathrm{O}_{3}$ catalyst with different ratios.

Table 2: Temperature for conversion of $\mathrm{CO}_{2}$ and $\mathrm{H}_{2} \mathrm{~S}$ over $\mathrm{Al}_{2} \mathrm{O}_{3}$ supported $\mathrm{Fe} / \mathrm{Zn} / \mathrm{Cu} / \mathrm{Ti}$ catalyst with different ratios using simulated natural gas.

\begin{tabular}{ccc}
\hline Catalyst & $\begin{array}{c}\mathrm{T}_{100} \mathrm{CO}_{2}{ }^{a} \\
\left( \pm 0.5^{\circ} \mathbf{C}\right)\end{array}$ & $\begin{array}{c}\mathrm{T}_{100} \mathrm{H}_{2} \mathrm{~S} \\
\left( \pm 0.5^{\circ} \mathrm{C}\right)\end{array}$ \\
\hline $\mathrm{Fe} / \mathrm{Zn} / \mathrm{Cu} / \mathrm{Ti}(10: 20: 30: 40)-\mathrm{Al}_{2} \mathrm{O}_{3}$ & $500(64.2 \%)^{\mathrm{b}}$ & 100 \\
$\mathrm{Fe} / \mathrm{Zn} / \mathrm{Cu} / \mathrm{Ti}(5: 5: 40: 50)-\mathrm{Al}_{2} \mathrm{O}_{3}$ & $500(75.2 \%)^{\mathrm{b}}$ & 100 \\
$\mathrm{Fe} / \mathrm{Zn} / \mathrm{Cu} / \mathrm{Ti}(5: 5: 30: 60)-\mathrm{Al}_{2} \mathrm{O}_{3}$ & $500(62.5 \%)^{\mathrm{b}}$ & 100 \\
\hline
\end{tabular}

Temperature where $100 \%$ conversion was achieved

${ }^{\circ}$ Value in bracket is the $\%$ conversion of $\mathrm{CO}_{2}$ at maximum studied temperature of $500{ }^{\circ} \mathrm{C}$

From Table 1 and 2, it could be concluded that $\mathrm{Fe} / \mathrm{Zn} / \mathrm{Cu}$ (4: 16: 80)- $\mathrm{Al}_{2} \mathrm{O}_{3}$ is the most potential catalyst for conversion of $\mathrm{CO}_{2}$. This showed that copper oxide acts as a better based element for $\mathrm{CO}_{2}$ conversion catalyst compared to TiO. Basu et al. [8] have proven that the addition of $\mathrm{TiO}$ at a high concentration may increase the surface oxygen storage. However, this property did not assist the adsorption of $\mathrm{CO}_{2}$ on the catalyst surface. Besides that, the interaction between $\mathrm{Ti}$ and $\mathrm{H}_{2}$ is weak because $\mathrm{H}_{2}$ prefer to adsorb on the defect TiO lattice. Thus, prevent the adsorption of $\mathrm{H}_{2}$ during $\mathrm{CO}_{2}$ methanation [9]. Table 2 also shows that all the three catalysts achieved $100 \%$ conversion of $\mathrm{H}_{2} \mathrm{~S}$ at reaction temperature of $100{ }^{\circ} \mathrm{C}$. However, $\mathrm{Fe} / \mathrm{Zn} / \mathrm{Cu} / \mathrm{Ti}$ (5: 5: 40: 50)- $\mathrm{Al}_{2} \mathrm{O}_{3}$ is considered as the most potential catalyst for desulfurization process due to its ability to convert higher percentage of $\mathrm{H}_{2} \mathrm{~S}$ at light off temperature ( $\mathrm{TLO}=60{ }^{\circ} \mathrm{C}$ ) compared to the other catalysts (not showed). $\mathrm{Fe} / \mathrm{Zn} / \mathrm{Cu} / \mathrm{Ti}(5: 5: 40: 50)-\mathrm{Al}_{2} \mathrm{O}_{3}$ gave $96.2 \%$ conversion of $\mathrm{H}_{2} \mathrm{~S}$ at TLO; $\mathrm{Fe} / \mathrm{Zn} / \mathrm{Cu} / \mathrm{Ti}(10: 20: 30: 40)-\mathrm{Al}_{2} \mathrm{O}_{3}$ catalyst gave 
$92.5 \%$ while $\mathrm{Fe} / \mathrm{Zn} / \mathrm{Cu} / \mathrm{Ti}$ (5: 5: 30: 60)- $\mathrm{Al}_{2} \mathrm{O}_{3}$ gave $87.3 \%$ conversion of $\mathrm{H}_{2} \mathrm{~S}$ at TLO. It has been proven that TiO could influence the dissociation of $\mathrm{H}_{2} \mathrm{~S}$ to $\mathrm{H}^{+}$and $\mathrm{HS}^{-}$at the early stage due to its weak electron interaction in the $d$ orbital [10].

\subsubsection{In-situ reactions of $\mathrm{CO}_{2}$ methanation and $\mathrm{H}_{2} \mathrm{~S}$ desulfurization}

In order to elucidate the performance of the catalysts under in-situ reactions of $\mathrm{CO}_{2}$ methanation and desulfurization condition, $\mathrm{Al}_{2} \mathrm{O}_{3}$ supported $\mathrm{Fe} / \mathrm{Zn} / \mathrm{Cu}$ and $\mathrm{Fe} / \mathrm{Zn} / \mathrm{Cu} / \mathrm{Ti}$ catalysts with the optimum ratio were tested using simulated natural gas environment. The selectivity and yield of $\mathrm{CH}_{4}$ was calculated by incorporating Gas Chromatography data due to the low sensitivity of FTIR towards stretching band of $\mathrm{CH}_{4}$. Figure 1 shows the percentage conversion of $\mathrm{H}_{2} \mathrm{~S}$ over Fe/Zn/Cu/Ti(5: 5: 40: 50) $-\mathrm{Al}_{2} \mathrm{O}_{3}$ catalyst is higher than $\mathrm{Fe} / \mathrm{Zn} / \mathrm{Cu}(4: 16: 80)-\mathrm{Al}_{2} \mathrm{O}_{3}$ catalyst. The graph shows a decrease on the conversion of $\mathrm{H}_{2} \mathrm{~S}$ from room temperature to $40^{\circ} \mathrm{C}$. This phenomenon was assigned to the adsorption of $\mathrm{H}_{2} \mathrm{~S}$ by the catalyst. Both catalysts, completely removed $\mathrm{H}_{2} \mathrm{~S}$ at reaction temperature of $100^{\circ} \mathrm{C}$. On the other hand, both catalysts gave a gradual increase for the conversion of $\mathrm{CO}_{2}$ until maximum reaction temperature of $200{ }^{\circ} \mathrm{C}$. $\mathrm{Fe} / \mathrm{Zn} / \mathrm{Cu}(4: 16: 80)-\mathrm{Al}_{2} \mathrm{O}_{3}$ catalyst showed a higher conversion of $\mathrm{CO}_{2}$ compared to $\mathrm{Fe} / \mathrm{Zn} / \mathrm{Cu} / \mathrm{Ti}(5: 5: 40: 50)-\mathrm{Al}_{2} \mathrm{O}_{3}$ catalyst. The catalytic activity of in-situ reactions over both catalysts slightly decreased compared to the individual reaction of $\mathrm{CO}_{2}$ methanation and $\mathrm{H}_{2} \mathrm{~S}$ desulfurization.

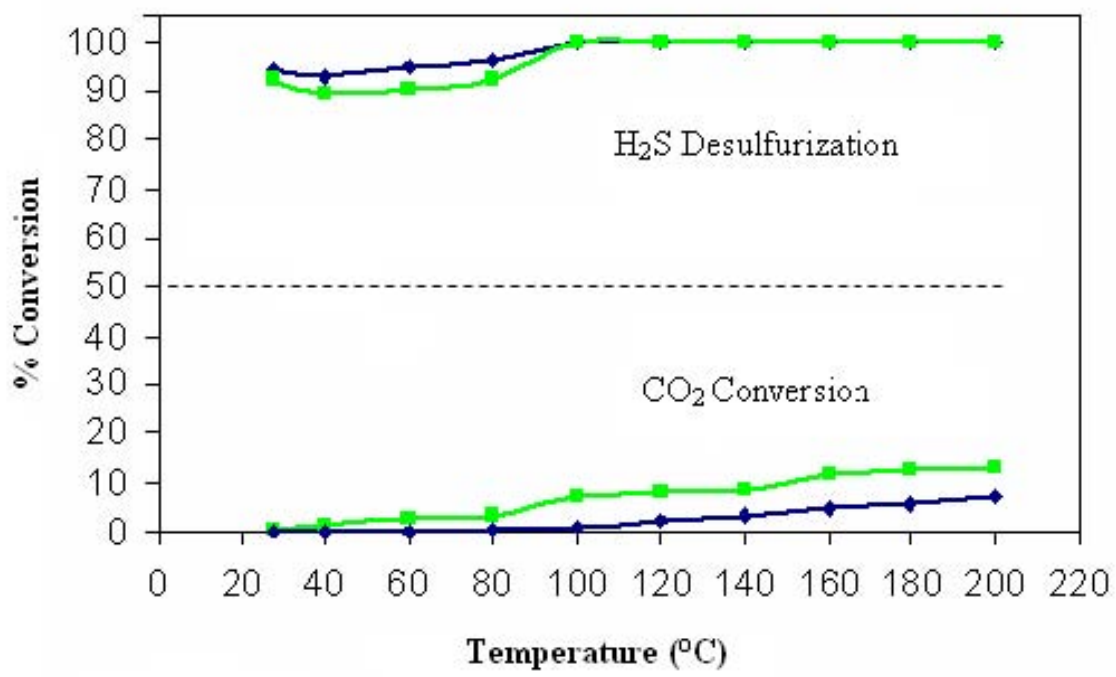

Figure 1: Percentage conversion of $\mathrm{CO}_{2}$ and $\mathrm{H}_{2} \mathrm{~S}$ versus reaction temperature under in-situ reactions of $\mathrm{CO}_{2}$ methanation and $\mathrm{H}_{2} \mathrm{~S}$ desulfurization over (๘) $\mathrm{Fe} / \mathrm{Zn} / \mathrm{Cu}(4: 16: 80)-\mathrm{Al}_{2} \mathrm{O}_{3}$ and (») $\mathrm{Fe} / \mathrm{Zn} / \mathrm{Cu} / \mathrm{Ti}$ (5: 5: 40: 50)- $\mathrm{Al}_{2} \mathrm{O}_{3}$ catalysts.

Table 3: Selectivity products of $i n$-situ reactions of $\mathrm{CO}_{2}$ methanation and $\mathrm{H}_{2} \mathrm{~S}$ desulfurization over the catalysts.

\begin{tabular}{ccccc}
\hline Catalyst & Temperature & \multicolumn{2}{c}{$\mathrm{CO}_{2}$ Conversion (\%) } & Unreacted \\
\cline { 3 - 4 } & $\left({ }^{\circ} \mathbf{C}\right)$ & $\mathrm{CH}_{4}$ & $\left(\mathbf{C O}+\mathbf{H}_{2} \mathbf{O}\right)$ & $\mathrm{CO}_{2}(\%)$ \\
\hline $\mathrm{Fe} / \mathrm{Zn} / \mathrm{Cu}(4: 16: 80)-\mathrm{Al}_{2} \mathrm{O}_{3}$ & 100 & 0.6 & 5.9 & 93.5 \\
& 200 & 0.7 & 11.3 & 88.0 \\
\hline $\mathrm{Fe} / \mathrm{Zn} / \mathrm{Cu} / \mathrm{Ti}(5: 5: 40: 50)-\mathrm{Al}_{2} \mathrm{O}_{3}$ & 100 & 0.0 & 0.7 & 99.3 \\
& 200 & 0.4 & 6.2 & 93.4 \\
\hline
\end{tabular}

* Calculation based on $\mathrm{CO}_{2}$ detected via FTIR and $\mathrm{CH}_{4}$ detected via $\mathrm{GC}$.

From Table 3, $\mathrm{Fe} / \mathrm{Zn} / \mathrm{Cu}(4: 16: 80)-\mathrm{Al}_{2} \mathrm{O}_{3}$ catalyst yielded $0.6 \%$ and $0.7 \%$ of $\mathrm{CH}_{4}$ at reaction temperature of $100^{\circ} \mathrm{C}$ and $200^{\circ} \mathrm{C}$ respectively. $\mathrm{Fe} / \mathrm{Zn} / \mathrm{Cu} / \mathrm{Ti}(5: 5: 40: 50)-\mathrm{Al}_{2} \mathrm{O}_{3}$ catalyst yielded no $\mathrm{CH}_{4}$ at $100{ }^{\circ} \mathrm{C}$ and only $0.4 \%$ of $\mathrm{CH}_{4}$ at $200^{\circ} \mathrm{C}$. The selectivity of $\mathrm{CH}_{4}$ over TiO based catalyst is considered very low. From the result, it could be considered that the conversion of $\mathrm{CO}_{2}$ to $\mathrm{CH}_{4}$ in this research is incomplete because higher percentage of $\mathrm{CO}$ formed rather than $\mathrm{CH}_{4}$ [11]. This 
is due to the indirect conversion of $\mathrm{CO}_{2}$ into $\mathrm{C} 1$ hydrocarbons, via intermediate formation of $\mathrm{CO}$, as suggested by Silver et al. [12].

\subsection{Characterization of the Catalysts}

\subsubsection{XPS}

The surface active components on the fresh and after testing (spent) catalysts of $\mathrm{Fe} / \mathrm{Zn} / \mathrm{Cu}$ (4: 16: 80)- $\mathrm{Al}_{2} \mathrm{O}_{3}$ and $\mathrm{Fe} / \mathrm{Zn} / \mathrm{Cu} / \mathrm{Ti}$ (5: 5: 40: 50)- $\mathrm{Al}_{2} \mathrm{O}_{3}$ was accomplished through XPS analysis. All data was corrected by using the binding energy of $\mathrm{C} 1 \mathrm{~s}$ at $284.5 \mathrm{eV}$ as standard. XPS analysis only detected the presence of $\mathrm{Cu}, \mathrm{Fe}, \mathrm{Al}$ and $\mathrm{O}$ on the surface. Even though the EDX analysis detected the weight percentage of $\mathrm{Zn}$ as $0.2 \%$ in the $\mathrm{Fe} / \mathrm{Zn} / \mathrm{Cu}(4: 16: 80)-\mathrm{Al}_{2} \mathrm{O}_{3}$ and $0.1 \%$ in the $\mathrm{Fe} / \mathrm{Zn} / \mathrm{Cu} / \mathrm{Ti}(5: 5: 40: 50)-\mathrm{Al}_{2} \mathrm{O}_{3}$ catalyst, no peak assigned to $\mathrm{Zn}$ was detected from the deconvolution peak of $\mathrm{Zn}$. This may due to the agglomeration of the other elements, which thus pushed $\mathrm{Zn}$ into the lattice structure of the catalyst or poisoning from carbon compound during XPS analysis [13]. In addition, the presence of Ti in the $\mathrm{Fe} / \mathrm{Zn} / \mathrm{Cu} / \mathrm{Ti}(5: 5: 40: 50)-\mathrm{Al}_{2} \mathrm{O}_{3}$ catalyst also could not be detected due to the narrow diameter of Ti compared to $\mathrm{Cu}$ and $\mathrm{Fe}$. It is believed that Ti was left inside the lattice structure of the catalyst. The interaction of electron from Ti was weak due to the distance of Ti inside the catalyst structure is comparably farer than those species on the surface.

The binding energy resulted from deconvolution peaks of $\mathrm{Cu}(2 p)$ from the studied catalysts were tabulated in Table 4. Both fresh catalysts of $\mathrm{Fe} / \mathrm{Zn} / \mathrm{Cu}(4: 16: 80)-\mathrm{Al}_{2} \mathrm{O}_{3}$ and $\mathrm{Fe} / \mathrm{Zn} / \mathrm{Cu} / \mathrm{Ti}$ (5: 5: 40: 50)- $\mathrm{Al}_{2} \mathrm{O}_{3}$ contained normal spinel compound of $\mathrm{CuFe}_{2} \mathrm{O}_{4}$. The normal spinel of $\mathrm{CuFe}_{2} \mathrm{O}_{4}$ on the $\mathrm{Fe} / \mathrm{Zn} / \mathrm{Cu}(4: 16: 80)-\mathrm{Al}_{2} \mathrm{O}_{3}$ catalyst turned to inverse spinel structure after the catalytic testing, while it remained as normal spinel structure for the spent $\mathrm{Fe} / \mathrm{Zn} / \mathrm{Cu} / \mathrm{Ti}(5: 5: 40: 50)-\mathrm{Al}_{2} \mathrm{O}_{3}$ catalyst. A normal spinel compound is the active site for the catalysts. $\mathrm{Fe} 3+$ made up the octahedral site while $\mathrm{Cu} 2+$ made up the tetrahedral site $[14,15]$. Analysis showed that $\mathrm{Fe} / \mathrm{Zn} / \mathrm{Cu}(4: 16: 80)-\mathrm{Al}_{2} \mathrm{O}_{3}$ and $\mathrm{Fe} / \mathrm{Zn} / \mathrm{Cu} / \mathrm{Ti}$ (5: 5: 40: 50)- $\mathrm{Al}_{2} \mathrm{O}_{3}$ catalysts contain spinel compound of $\mathrm{CuFe}_{2} \mathrm{O}_{4}$ or $\mathrm{Fe}_{3} \mathrm{O}_{4}$ that are assumed to act as active species on the surface. $\mathrm{Fe}_{3} \mathrm{O}_{4}$ is considered as the most dominant structure compared to $\mathrm{CuFe}_{2} \mathrm{O}_{4}$ and it is also the active site for $\mathrm{H}_{2} \mathrm{~S}$ desulfurization.

Table 4: XPS data of $\mathrm{Cu}(2 p)$ for $\mathrm{Fe} / \mathrm{Zn} / \mathrm{Cu}-\mathrm{Al}_{2} \mathrm{O}_{3}$ and $\mathrm{Fe} / \mathrm{Zn} / \mathrm{Cu} / \mathrm{Ti}-\mathrm{Al}_{2} \mathrm{O}_{3}$ catalysts.

\begin{tabular}{|c|c|c|c|c|c|c|}
\hline \multirow[t]{2}{*}{ Catalyst } & \multirow[t]{2}{*}{$\begin{array}{l}\text { Weight } \\
(\%)\end{array}$} & \multicolumn{2}{|c|}{$\begin{array}{l}\text { Binding Energy } \\
(\mathrm{eV})^{2}\end{array}$} & \multirow[t]{2}{*}{$\begin{array}{l}\Delta E_{S O}{ }^{b} \\
(e V)\end{array}$} & \multirow{2}{*}{$\begin{array}{l}\text { Peak } \\
\text { Area }^{c} \\
\left(2 p_{3 / 2}\right)\end{array}$} & \multirow[t]{2}{*}{ Peak Assignment } \\
\hline & & $2 p_{3 / 2}$ & $2 p_{1 / 2}$ & & & \\
\hline $\begin{array}{c}\mathrm{Fe} / \mathrm{Zn} / \mathrm{Cu}(4: 16: 80)-\mathrm{Al}_{2} \mathrm{O}_{3} \\
\text { (fresh) }\end{array}$ & 1.8 & 933.7 & 953.6 & 19.9 & 21.6 & $\begin{array}{c}\mathrm{CuFe}_{2} \mathrm{O}_{4} \\
\text { (normal spinel) }\end{array}$ \\
\hline $\begin{array}{c}\mathrm{Fe} / \mathrm{Zn} / \mathrm{Cu}(4: 16: 80)-\mathrm{Al}_{2} \mathrm{O}_{3} \\
\text { (spent) }\end{array}$ & 4.2 & 935.1 & 954.9 & 19.8 & 23.9 & $\begin{array}{c}\mathrm{CuFe}_{2} \mathrm{O}_{4} \\
\text { (inverse spinel) }\end{array}$ \\
\hline $\begin{array}{c}\mathrm{Fe} / \mathrm{Zn} / \mathrm{Cu} / \mathrm{Ti}(5: 5: 40: 50)- \\
\mathrm{Al}_{2} \mathrm{O}_{3} \text { (fresh) }\end{array}$ & 3.6 & 933.6 & 953.5 & 19.9 & 247.6 & $\begin{array}{c}\mathrm{CuFe}_{2} \mathrm{O}_{4} \\
\text { (normal spinel) }\end{array}$ \\
\hline $\begin{array}{c}\mathrm{Fe} / \mathrm{Zn} / \mathrm{Cu} / \mathrm{Ti}(5: 5: 40: 50)- \\
\mathrm{Al}_{2} \mathrm{O}_{3} \text { (spent) }\end{array}$ & 3.7 & 933.7 & 953.5 & 19.9 & 59.9 & $\begin{array}{c}\mathrm{CuFe}_{2} \mathrm{O}_{4} \\
\text { (normal spinel) }\end{array}$ \\
\hline
\end{tabular}

Peaks referred to normal spinel compounds of $\mathrm{CuFe}_{2} \mathrm{O}_{4}$ or $\mathrm{Fe}_{3} \mathrm{O}_{4}$ appeared at binding energy of $710.1 \mathrm{Ev}(2 p 3 / 2)$ and $723.7 \mathrm{eV}(2 p 1 / 2)$ for $\mathrm{Fe} / \mathrm{Zn} / \mathrm{Cu}(4: 16: 80)-\mathrm{Al}_{2} \mathrm{O}_{3}$ catalyst, $709.7 \mathrm{eV}(2 p 3 / 2)$ and $723.2 \mathrm{eV}(2 p 1 / 2)$ for $\mathrm{Fe} / \mathrm{Zn} / \mathrm{Cu} / \mathrm{Ti}(5: 5: 40$ : 50)- $\mathrm{Al}_{2} \mathrm{O}_{3}$ catalyst (Table 5). Peak area of these peaks is high enough, which indicated the formation of surface Fe in a large amount. This also proved that $\mathrm{Fe}_{3} \mathrm{O}_{4}$ is a more dominant structure compared to $\mathrm{CuFe}_{2} \mathrm{O}_{4}$. There are another peaks at binding energy of $712.4 \mathrm{eV}(2 p 3 / 2)$ and $726.1 \mathrm{eV}(2 p 1 / 2)$ for $\mathrm{Fe} / \mathrm{Zn} / \mathrm{Cu} / \mathrm{Ti}(5: 5: 40: 50)-\mathrm{Al}_{2} \mathrm{O}_{3}$ catalyst assigned to the $\mathrm{Fe} 3+$ bound to hydroxyl group (-OH) and is in agreement with Shah et al. [16]. The high binding energy of these peaks is due to the high electronegativity of hydroxyl group. $-\mathrm{OH}$ ligand is more electronegative than oxygen. The presence of hydroxyl ligand could increase the oxidation reaction over $\mathrm{Fe} / \mathrm{Zn} / \mathrm{Cu} / \mathrm{Ti}(5: 5: 40: 50)-\mathrm{Al}_{2} \mathrm{O}_{3}$ catalyst due to its high electron density nature. Morrison [13] also proved that $\mathrm{TiO}_{2}$ in $\mathrm{Fe} / \mathrm{Zn} / \mathrm{Cu} / \mathrm{Ti}(5: 5: 40: 50)-\mathrm{Al}_{2} \mathrm{O}_{3}$ catalyst contributed to the presence of $\mathrm{Fe}^{3+}-\mathrm{OH}$ and thus active site for the $\mathrm{H}_{2} \mathrm{~S}$ desulfurization. Thus, the adsorption process of $\mathrm{H}_{2} \mathrm{~S}$ at low temperature that may inhibit $\mathrm{H}_{2} \mathrm{~S}$ desulfurization could be avoided. 
On the other hand, the spent $\mathrm{Fe} / \mathrm{Zn} / \mathrm{Cu}$ (4: 16: 80)- $\mathrm{Al}_{2} \mathrm{O}_{3}$ catalyst showed the deconvolution peaks of $\mathrm{CuFe}_{2} \mathrm{O}_{4}$ or $\mathrm{Fe}_{3} \mathrm{O}_{4}$ at binding energy of $710.1 \mathrm{eV}(2 p 3 / 2)$ and $723.7 \mathrm{eV}(2 p 1 / 2)$ but with $85.3 \%$ reduction of peak area. This is due to the occurance of inverse spinel structure that contributed to the presence of larger amount of surface $\mathrm{Cu}$. The spent catalyst of $\mathrm{Fe} / \mathrm{Zn} / \mathrm{Cu} / \mathrm{Ti}$ (5: 5: 40: 50)- $\mathrm{Al}_{2} \mathrm{O}_{3}$ also showed a lower peak area for the deconvolution peaks of $\mathrm{CuFe}_{2} \mathrm{O}_{4}$ or $\mathrm{Fe}_{3} \mathrm{O}_{4}$ at 710.5 $\mathrm{eV}(2 p 3 / 2)$ and $724.1 \mathrm{eV}(2 p 1 / 2)$. The formation of $\mathrm{CuO}$ obstructed the distribution of $\mathrm{Fe}$ on the catalyst surface.

Table 5: XPS data of $\mathrm{Fe}(2 p)$ for $\mathrm{Fe} / \mathrm{Zn} / \mathrm{Cu}(4: 16: 80)-\mathrm{Al}_{2} \mathrm{O}_{3}$ and $\mathrm{Fe} / \mathrm{Zn} / \mathrm{Cu} / \mathrm{Ti}(5: 5: 40: 50)-\mathrm{Al}_{2} \mathrm{O}_{3}$ catalysts.

\begin{tabular}{|c|c|c|c|c|c|c|}
\hline \multirow[t]{2}{*}{ Catalyst } & \multirow[t]{2}{*}{$\begin{array}{c}\text { Weight } \\
(\%)\end{array}$} & \multicolumn{2}{|c|}{$\begin{array}{c}\text { Binding Energy } \\
(\mathrm{eV})^{\mathrm{a}}\end{array}$} & \multirow[t]{2}{*}{$\begin{array}{l}\Delta E_{S_{0}}{ }^{\circ} \\
(\mathrm{eV})\end{array}$} & \multirow{2}{*}{$\begin{array}{l}\text { Peak } \\
\text { Area }^{c} \\
\left(2 p_{3 / 2}\right)\end{array}$} & \multirow[t]{2}{*}{$\begin{array}{c}\text { Peak } \\
\text { Assignment }\end{array}$} \\
\hline & & $2 p_{32}$ & $2 p_{12}$ & & & \\
\hline $\mathrm{Fe} / \mathrm{Zn} / \mathrm{Cu}(4: 16: 80)-\mathrm{Al}_{2} \mathrm{O}_{3}$ (fresh) & 3.6 & 710.1 & 723.7 & 13.6 & 66.7 & $\begin{array}{c}\mathrm{CuFe}_{2} \mathrm{O}_{4} / \\
\mathrm{Fe}_{3} \mathrm{O}_{4}\end{array}$ \\
\hline $\mathrm{Fe} / \mathrm{Zn} / \mathrm{Cu}(4: 16: 80)-\mathrm{Al}_{2} \mathrm{O}_{3}$ (spent) & 3.4 & 710.1 & 723.7 & 13.6 & 9.8 & $\begin{array}{c}\mathrm{CuFe}_{2} \mathrm{O}_{4} / \\
\mathrm{Fe}_{3} \mathrm{O}_{4}\end{array}$ \\
\hline $\begin{array}{c}\mathrm{Fe} / \mathrm{Zn} / \mathrm{Cu} / \mathrm{Ti}(5: 5: 40: 50)-\mathrm{Al}_{2} \mathrm{O}_{3} \\
\text { (fresh) }\end{array}$ & 3.8 & $\begin{array}{r}709.7 \\
712.4 \\
\end{array}$ & 723.2 & 13.5 & $\begin{array}{l}12.5 \\
6.4 \\
\end{array}$ & $\begin{array}{c}\mathrm{CuFe}_{2} \mathrm{O}_{4} / \\
\mathrm{Fe}_{3} \mathrm{O}_{4} \\
\mathrm{Fe}^{3+}-\mathrm{OH}\end{array}$ \\
\hline $\begin{array}{c}\mathrm{Fe} / \mathrm{Zn} / \mathrm{Cu} / \mathrm{Ti}(5: 5: 40: 50)- \\
\mathrm{Al}_{2} \mathrm{O}_{3} \text { (spent) }\end{array}$ & 2.8 & 710.5 & 724.1 & 13.6 & 10.0 & $\begin{array}{c}\mathrm{CuFe}_{2} \mathrm{O}_{4} / \\
\mathrm{Fe}_{3} \mathrm{O}_{4}\end{array}$ \\
\hline
\end{tabular}

Table 6: BET surface area and BJH desorption average pore diameter of the fresh supported catalysts and after in-situ reactions testing catalysts

\begin{tabular}{lcc}
\hline \multicolumn{1}{c}{ Catalyst } & $S_{\mathrm{BET}}\left(\mathrm{m}^{2} \mathrm{~g}^{-1}\right)$ & $\mathrm{d}(\mathrm{nm})$ \\
\hline $\mathrm{Fe} / \mathrm{Zn} / \mathrm{Cu}(4: 16: 80)-\mathrm{Al}_{2} \mathrm{O}_{3}$ (fresh) & 184.8 & 5.1 \\
$\mathrm{Fe} / \mathrm{Zn} / \mathrm{Cu}(4: 16: 80)-\mathrm{Al}_{2} \mathrm{O}_{3}$ (spent) & 121.6 & 7.1 \\
$\mathrm{Fe} / \mathrm{Zn} / \mathrm{Cu} / \mathrm{Ti}(5: 5: 40: 50)-\mathrm{Al}_{2} \mathrm{O}_{3}$ (fresh) & 259.2 & 2.6 \\
$\mathrm{Fe} / \mathrm{Zn} / \mathrm{Cu} / \mathrm{Ti}(5: 5: 40: 50)-\mathrm{Al}_{2} \mathrm{O}_{3}$ (spent) & 215.6 & 3.2 \\
\hline
\end{tabular}

Table 7: Elemental composition of $\mathrm{Fe} / \mathrm{Zn} / \mathrm{Cu}$ (4: 16: 80)- $\mathrm{Al}_{2} \mathrm{O}_{3}$ and $\mathrm{Fe} / \mathrm{Zn} / \mathrm{Cu} / \mathrm{Ti}$ (5: 5: 40: 50)- $\mathrm{Al}_{2} \mathrm{O}_{3}$ catalysts analyzed by Energy Dispersive X-rays Analysis.

\begin{tabular}{l|l|r|c|c|c|c|c|c}
\hline \multirow{2}{*}{\multicolumn{1}{c|}{ Catalyst }} & \multirow{2}{*}{ Condition } & \multicolumn{7}{c}{ Atomic Weight Percentage (\%) } \\
\cline { 3 - 9 } & & $\mathrm{Ti}_{1}$ & $\mathrm{Cu}$ & $\mathrm{Zn}$ & $\mathrm{Fe}$ & $\mathrm{S}$ & $\mathrm{Al}$ & $\mathrm{O}$ \\
\hline $\mathrm{Fe} / \mathrm{Zn} / \mathrm{Cu} / \mathrm{Ti}(5:$ & Before testing & 4.90 & 3.88 & 0.48 & 0.47 & 0.00 & 40.41 & 49.86 \\
$5: 40: 50)-\mathrm{Al}_{2} \mathrm{O}_{3}$ & After testing & 4.82 & 3.80 & 0.43 & 0.41 & 1.43 & 39.94 & 49.17 \\
& After regeneration & 4.89 & 3.87 & 0.46 & 0.45 & 0.00 & 40.22 & 50.11 \\
\hline $\mathrm{Fe} / \mathrm{Zn} / \mathrm{Cu}(4: 16:$ & Before testing & 0.00 & 14.83 & 3.68 & 0.74 & 0.00 & 49.12 & 31.63 \\
$80)-\mathrm{Al}_{2} \mathrm{O}_{3}$ & After testing & 0.00 & 14.75 & 3.64 & 0.70 & 2.32 & 48.64 & 29.95 \\
& After regeneration & 0.00 & 14.84 & 3.65 & 0.73 & 0.00 & 50.06 & 30.72 \\
\hline
\end{tabular}

\subsubsection{Nitrogen Adsorption Analysis}

One of the most characteristic properties of the surface of a solid is its ability to adsorb gases and vapours. Table 6 summarized the BET surface area and BJH desorption average pore diameter of the fresh supported catalysts and after insitu reactions testing catalysts (spent catalysts). The fresh catalysts showed relatively narrow pore size compared to the spent catalysts. It could be seen that $\mathrm{Fe} / \mathrm{Zn} / \mathrm{Cu} / \mathrm{Ti}$ (5: 5: 40:50)- $\mathrm{Al}_{2} \mathrm{O}_{3}$ catalyst posseses higher surface area and narrower pore size. This was supported by Yamasaki et al. [17] that the addition of $\mathrm{TiO} 2$ in the catalyst may increase the surface area 
and decrease the particle size. These features improved the $\mathrm{H}_{2} \mathrm{~S}$ desulfurization activity but not the $\mathrm{CO}_{2}$ methanation activity. However, the catalytic activity of a particular catalyst not only depends on the BET surafce area and pore size, but also included other factors such as type of pores, shape of pores and the degree of porosity [18].

From the BET surface area analysis, the $\mathrm{Fe} / \mathrm{Zn} / \mathrm{Cu}(4: 16: 80)-\mathrm{Al}_{2} \mathrm{O}_{3}$ catalyst showed reduction of $34 \%$ and $\mathrm{Fe} / \mathrm{Zn} / \mathrm{Cu} / \mathrm{Ti}(5: 5: 40: 50)-\mathrm{Al}_{2} \mathrm{O}_{3}$ catalyst showed reduction of $17 \%$ in surface area. This reduction was possibly due to the sulfur poisoning on the surface during $\mathrm{H}_{2} \mathrm{~S}$ desulfurization. This was also proven by the Energy Dispersive X-rays Analysis (Table 7). However, the isotherm plot of the fresh and spent catalysts did not show significant difference. All the catalysts showed Type IV isotherm plot and H3 type hysteresis loop resemblance with slit-shaped pores and with non-uniform shape and size.

\section{CONCLUSION}

The optimum ratio for $\mathrm{Al}_{2} \mathrm{O}_{3}$ supported $\mathrm{CuO}$ based catalyst obtained was $\mathrm{Fe} / \mathrm{Zn} / \mathrm{Cu}=4: 16: 80$, while for $\mathrm{TiO}$ based catalyst was $\mathrm{Fe} / \mathrm{Zn} / \mathrm{Cu} / \mathrm{Ti}=5: 5: 40: 50$. Both of the catalysts completely converted $\mathrm{H}_{2} \mathrm{~S}$ to elemental sulfur at reaction temperature of $100^{\circ} \mathrm{C}$. The aim to obtain high $\mathrm{H}_{2} \mathrm{~S}$ desulfurization rate at low temperature was achieved. The introduction of $\mathrm{Fe}, \mathrm{Zn}, \mathrm{Cu}$ and $\mathrm{Ti}$ intended to catalyze the $\mathrm{CO}_{2} / \mathrm{H}_{2}$ methanation reaction in the presence of $\mathrm{H}_{2} \mathrm{~S}$ proved ineffective in this case. However, it has been observed that $\mathrm{Fe} / \mathrm{Zn} / \mathrm{Cu}$ (4: 16: 80) $-\mathrm{Al}_{2} \mathrm{O}_{3}$ catalyst showed a higher conversion and also $\mathrm{CH}_{4}$ formation compared to $\mathrm{Fe} / \mathrm{Zn} / \mathrm{Cu} / \mathrm{Ti}(5: 5: 40: 50)-\mathrm{Al}_{2} \mathrm{O}_{3}$. The catalytic activities of in-situ reactions over both catalysts showed a slightly decrease compared to the individual reaction of $\mathrm{CO}_{2}$ methanation and $\mathrm{H}_{2} \mathrm{~S}$. Therefore, further efforts are needed in the future work in the attempt to obtain catalysts that may increase the conversion rate of $\mathrm{CO}_{2}$ and $\mathrm{H}_{2} \mathrm{~S}$ simultaneously.

\section{ACKNOWLEDGEMENT}

The authors are gratefully acknowledged to the Ministry of Science, Technology and Innovation, Malaysia for IRPA Vot 74248 and Universiti Teknologi Malaysia for financial support.

\section{REFERENCES}

[1] O.V. Krylov, A.Kh. Mamedov, S.R. Mirzabekova, Catal. Today. 42 (1998) 211-215.

[2] S.G. Wang, X.Y. Liao, D.B. Cao, C.F. Huo, Y.W. Li, J.G. Wang, H.J. Jiao, J. Phys. Chem. C. 111 (2007) 16934-16940.

[3] I. E. Wachs, Catal. Today. 100 (2005) 79-94.

[4] S.K. Kulshreshtha, R. Sasikala, N.M. Gupta, R.M. Iyer, Catal. Lett. 4 (1990) 129-138.

[5] M. Pineda, J.L.G. Fierro, J.M. Palacios, E.G. Cilleruelo, J.V. Ibarra, Appl. Surf. Sci. 119 (1997) 1-10.

[6] J. Happel, M.A. Hnatow, U.S. Patent. 4, 260, 553. (1981).

[7] K. Sasaki, J. Maier, Solid State Ionics. 161 (2003) 145-154.

[8] B. Basu. J. Vleugels, O.V. Der Biest, , Mater. Sci. Eng., A. 366 (2004) 338-347.

[9] V.E. Henrich, P.A. Cox, The Surface Science of Metal Oxides, Cambridge University Press, Great Britain, 1994.

[10] M.A. Blesa, P.J. Morando, A.E. Regazzoni, Chemical Dissolution of Metal Oxides, CRC Press, Inc., 1993.

[11] W.A. Wan Abu Bakar, M.Y. Othman, R. Ali, K.Y. Ching, and S. Toemen, Modern Applied Science, 3(2), (2009) 35-43

[12] R.G. Silver, N.B. Jackson, and J.G. Ekerdt, Catalytic activation of Carbon Dioxide. (1988). Washington, DC: American Chemical Society, pp. 123-132.

[13] S.R. Morrison, Catal. Sci. Tech. 3 (1998) 199-229.

[14] H. Ando, M. Fujiwara, Y. Matsumura, H. Miyamura, H. Tanaka, Y. Souma, J. Alloys Compd. 223 (1998) 139-141.

[15] H. Ando, X. Qiang, M. Fujiwara, Y. Matsumura, H. Tanaka, Y. Souma, Catal. Today. 45 (1998) 229-234.

[16] P. Shah, M. Shoma, K. Kawaguchi, I. Yamaguchi, J. Magn. Magn. Mater. 214 (2002) 1-5.

[17] M. Yamasaki, M. Komori, E. Akiyama, H. Habazaki, A. Kawashima, K.Asami, K. Hashimoto, Mater. Sci. Eng., A. 267 (1999) $220-226$.

[18] N.A. Buang, Zr Based Catalysis for Environmental Emission Control: Synthesis, Characterization and Catalytic Activity. Universiti Teknologi Malaysia. Ph.D. Thesis, 2000, 53-68. 